INTERLEUKIN - 10 (IL-10) is a cytokine derived from $\mathrm{CD}_{4}^{+}$ T-helper type $2\left(\mathbf{T}_{\mathrm{H} 2}\right)$ cells identified as a suppressor of cytokines from T-helper type $1\left(\mathrm{~T}_{\mathrm{H} 1}\right)$ cells. Interleukin-12 (IL-12) is produced by $B$ cells, macrophages and dendritic cells, and primarily regulates $T_{H 1}$ cell differentiation, while suppressing the expansion of $\mathbf{T}_{\mathrm{H} 2}$ cell clones. Interferon- $\gamma($ IFN- $\gamma$ ) is a product of $T_{H 1}$ cells and exerts inhibitory effects on $T_{H 2}$ cell differentiation. These cytokines have been implicated in the pathogenesis of asthma and allergies. In this context, IL-12 and IFN- $\gamma$ production in asthma have been found to be decreased, and this may reduce their capacity to inhibit IgE synthesis and allergic inflammation. IL-10 is a potent inhibitor of monocyte/ macrophage function, suppressing the production of many pro-inflammatory cytokines. A relative underproduction of IL-10 from alveolar macrophages of atopic asthmatics has been reported. Therapeutic modulation of $T_{H_{1}} / T_{H_{2}}$ imbalance in asthma and allergy by mycobacterial vaccine, specific immunotherapy and cytoline-guanosine dinucleotide motif may lead to increases in IL-12 and IFN- $\gamma$ production. Stimulation of IL-10 production by antigen-specific T-cells during immunotherapy may lead to anergy through inhibition of CD28-costimulatory molecule signalling by IL-10s anti-inflammatory effect on basophils, mast cells and eosinophils.

Key words: Interleukin-10, Interleukin-12, interferon- $\gamma$, T-helper 1 and 2 cells, Asthma, Allergy

\section{Anti-inflammatory cytokines in asthma and allergy: interleukin-10, interleukin-12, interferon- $\gamma$}

\author{
Fan Chung ${ }^{\mathrm{CA}}$
}

National Heart \& Lung Institute, Imperial College School of Medicine, London SW3 6LY, UK

\author{
${ }^{\mathrm{CA}}$ Corresponding Author \\ Tel: +44(0)207352 8121 ext. 3052/8 \\ Fax: +44 (0)2073518126 \\ E-mail: f.chung@ic.ac.uk
}

\section{Introduction}

The chronic airway inflammation of asthma is characterised by infiltration of the airway wall by diverse effector cells, including T lymphocytes, eosinophils, monocytes/macrophages, mast cells, and occasionally, neutrophils. ${ }^{1-3}$ The airway wall undergoes chronic structural changes labelled as remodelling, which include thickening of the airway smooth muscle due to hypertrophy and hyperplasia, myofibroblast activation with increase in subepithelial basement membrane collagen deposition, angiogenesis and increase in submucosal blood vessels and an increase in goblet cell numbers in the airway epithelium. ${ }^{4,5}$ The mobilisation, activation and trafficking of effector cells to the airway are controlled by a complex cytokine milieu derived from activated CD4+ $\mathrm{T}_{\text {Helper }}\left(\mathrm{T}_{\mathrm{H}}\right)$ cells and also from other resident airway cells including airway smooth muscle and epithelial cells. $\mathrm{T}_{\mathrm{Helper}}$ cells of type 2 variety $\left(\mathrm{T}_{\mathrm{H} 2}\right)$ secrete a $\mathrm{T}_{\mathrm{H} 2}$ profile of cytokines, after cognate stimulation of the naïve T-cell by antigen presenting cells, such as the dendritic cell and the alveolar macrophage. $\mathrm{T}_{\mathrm{H} 2}$ cytokines include IL-4, IL-5, IL-9, IL10 and IL-13. These cytokines promote various elements of allergic inflammation including propaga- tion of the $\mathrm{T}_{\mathrm{H} 2}$ phenotype, isotype-switching from $\operatorname{IgG}_{1}$ to IgE synthesis, eosinophil mobilisation, maturation and activation and mast cell activation. ${ }^{6}$ Chronic airway structural changes too are variably influenced by $\mathrm{T}_{\mathrm{H} 2}$ cytokines, and certain growth factors.

$T_{\mathrm{H} 1}$ cells form a natural counterbalance to $\mathrm{T}_{\mathrm{H} 2}$ cells driving protective cell-mediated immunity, and are induced on exposure to foreign agents including protozoa, bacteria and viral particles. $\mathrm{T}_{\mathrm{H} 1}$ responses are characterised by the induction of cell mediated immune responses and the synthesis of $\operatorname{IgG}_{2 \mathrm{a}}$, while $\mathrm{T}_{\mathrm{H} 2}$ responses are of humoral-type, inciting the production of IgE and $\operatorname{IgG}_{4} \mathrm{~T}_{\mathrm{H} 1}$ responses inhibit $\mathrm{T}_{\mathrm{H} 2}$ responses through the production of cytokines such as IL-12 and IFN- $\gamma$. There is evidence for a preferential skewing to the expansion of the $\mathrm{CD} 4+\mathrm{T}_{\mathrm{H} 2}$ lymphocyte subset in allergic processes, while CD4+ $\mathrm{T}_{\mathrm{H} 1}$ responses may be subdued and this is a likely crucial forerunner to development of allergic asthma. In this context, the $\mathrm{T}_{\mathrm{H} 1}$ cytokines, IL-12 and IFN- $\gamma$, may be considered to be 'anti-inflammatory' in that they inhibit certain responses attributable to $\mathrm{T}_{\mathrm{H} 2}$ cell activation, while the $\mathrm{T}_{\mathrm{H} 2}$ cytokine, IL-10, under certain circumstances, may inhibit pro-inflammatory activation of certain cells. The manipulation of the immune allergic system to promote $\mathrm{T}_{\mathrm{H} 1}$ responses 
involves the upregulation of IL-12 and INF $\gamma$, and under certain circumstances, of IL-10, which can prevent the establishment of allergy and of various manifestations of allergic inflammation.

In this review, the important roles of IFN- $\gamma$, IL-10 and IL-12 in inducing the therapeutic benefits of various immune therapies for allergy and asthma will be examined first, followed by a systematic review of these anti-inflammatory cytokines.

\section{Immunological imbalance of $T_{\mathrm{H} 1} \& T_{\mathrm{H} 2}$ cells}

The vast majority of asthmatics have an atopic background, in whom the inflammatory process of asthma may be driven following sensitisation and exposure to common aeroallergens to which they become sensitised to. Allergen-derived peptides are usually taken up by specialised cells on mucosal surfaces such as dendritic cells, and subsequently processed and presented to naïve T-cells. The activation of naïve T-cells requires direct signalling by 2 distinct pathways: firstly via the CD4+ T-cell receptor through the antigen-presenting cell (APC)-bound antigen to MHC-II complex and, secondly, via the costimulatory pathway linked by the $\mathrm{B} 7$ family and T-cell bound CD28. ${ }^{7}$ T-cells stimulated via the T-cell receptor (TCR) in the absence of co-stimulatory signalling are incapable of IL-2 secretion and subsequent activation and therefore enter an anergic state. ${ }^{8}$ CD28 itself has 2 major ligands, B7.1 which inhibits $\mathrm{T}_{\mathrm{H} 2}$ cell activation and development, and B7.2, which induces T-cell activation, and $\mathrm{T}_{\mathrm{H} 2}$ development. An important third ligand, CTLA4, is expressed on activated $\mathrm{T}$ cells, binds CD28 with enhanced avidity and acts as a negative regulator of T-cell function by inhibiting $\mathrm{T}_{\mathrm{H} 2}$ differentiation. ${ }^{9,10}$ In those who later develop an allergic response, naïve $\mathrm{T}$ cells differentiate into the $\mathrm{T}_{\mathrm{H} 2}$ subtype. This differentiation is induced by cytokines themselves, and may be secreted by antigen-stimulated $T$ cells themselves, or by other cells that become activated by $\mathrm{T}$ cell cytokines. IFN- $\gamma$ secreted by $\mathrm{T}_{\mathrm{H} 1}$ cells activate macrophages and dendritic cells, and in turn induces them to produce $\mathrm{IL}-12$, the main $\mathrm{T}_{\mathrm{H} 1^{-}}$ inducing cytokine. $\mathrm{T}_{\mathrm{H} 1}$ and $\mathrm{T}_{\mathrm{H} 2}$ cells produce cytokines that cross-regulate and antagonise each other's activity and development. IL- 4 can inhibit IL-12 production, and $\mathrm{T}_{\mathrm{H} 2}$ cytokines (IL-4, -10 and -13) antagonise the macrophage-activating properties of $\mathrm{T}_{\mathrm{H} 1}$ cytokines. IFN- $\gamma$ is involved in the $\mathrm{T}_{\mathrm{H} 1}$ inhibition of the effects of $\mathrm{T}_{\mathrm{H} 2}$ cells, such as bronchial hyperesponsiveness, eosinophilia and mucus goblet cell hyperplasia. ${ }^{11,12}$

T-cell profiles in the newborn demonstrate a $\mathrm{T}_{\mathrm{H} 2}$ bias suggesting that prenatal influences are involved in T-cell priming. ${ }^{13}$ During the course of maturation of the normal infant, however, increased $\mathrm{T}_{\mathrm{H} 1}$ expression occurs and the $\mathrm{T}_{\mathrm{H} 2}$ imbalance is overcome. ${ }^{14}$ Delay or failure of this $\mathrm{T}_{\mathrm{H} 1}$ response may result in $\mathrm{T}_{\mathrm{H} 2}$ persistence and atopy or atopic disease, and in infants destined to become atopic, circulating lymphocytes have impaired production of IFN- $\gamma \cdot{ }^{15}$ Recently, a 'hygiene hypothesis' has been put forward stating that a diminished induction of $\mathrm{T}_{\mathrm{H} 1}$ responses is a potential explanation for the rising prevalence of atopy and asthma. ${ }^{13,16}$ Cross-sectional surveys have identified inverse relationships between prior microbial exposure and development of atopy. ${ }^{15,17}$ Further, respiratory allergy appears less frequently in those heavily exposed to orofaecal and foodborne microbes. ${ }^{16}$ Improved hygiene, early infection and antibiotic use, and a westernised or semi-sterile diet may facilitate atopy by influencing exposure to commensals and pathogens that stimulate immune cell populations such as gut-associated lymphoid tissue. ${ }^{18,19}$ Thus, early environmental exposure may be a determinant of the development of atopy in the adult. ${ }^{20}$ The identification of ways to prevent, control or even reverse the process of $\mathrm{T}_{\mathrm{H} 2}$ immunodeviation has become a focus for the development of new strategies to control asthma and allergies.

\section{Therapeutic $\mathrm{T}_{\mathrm{H} 1} / \mathrm{T}_{\mathrm{H} 2}$ modulation: roles of IL-10, IL-12 and IFN- $\gamma$}

The potential therapeutic roles of IL-10, IL-12 and IFN- $\gamma$ in allergies and asthma are well illustrated by various potential treatments. Specific immunotherapy (SIT) by administration of allergen extracts is a treatment aimed at the induction of specific unresponsiveness, or anergy, in peripheral T-cells to peptide epitopes. This treatment has been successfully used in asthma and allergic rhinitis and for venom allergy, ${ }^{21,22}$ but is usually most useful in subjects allergic to single allergens such as grass pollens, and in subjects with mild forms of allergic diseases. $^{23,24}$. Peripheral T-cells following SIT are characterised by reduced IL- 4 and IL-5, and increased IFN- $\gamma$ production by CD4+ T cells $s^{25-27}$ and by attenuated proliferative responses to specific allergens. ${ }^{28}$ This process is initiated by an autocrine effect of IL-10 produced by antigen-specific T-cells. ${ }^{29-31}$ IL-10 induces anergy by inhibition of CD28-costimulatory molecule signaling, ${ }^{32,33}$ and also by anti-inflammatory effects on basophils, mast cells and eosinophils. There are reduced levels of IL- 4 and IL-5 and increased IFN- $\gamma$ production, indicating a shift of the $T$ cells towards an increased $T_{H 1}$ response at the expense of $\mathrm{T}_{\mathrm{H} 2}$ responses. ${ }^{25,26}$ After successful grass pollen immunotherapy, there is also an increase in IL-12 and IFN- $\gamma$ mRNA expression in tissues. ${ }^{34,35}$

The potential benefit of the mycobacterial vaccine, Bacille-Calmette-Guerin (BCG) (Mycobacterium bovis) vaccination, in atopic diseases was suggested 
by the association between BCG vaccination and diminished incidence of atopy and allergic disease in Japanese schoolchildren, indicating a role for early mycobacterial exposure in the subsequent development of atopic responsiveness. ${ }^{15}$ Mice vaccinated with BCG prior to allergen sensitisation had increased IFN- $\gamma$ and decreased IL- 4 and IL-5 expression along with reduced levels of airway T-cells and eosinophilia and bronchial reactivity. ${ }^{36,37}$ Local production of IFN$\gamma$ induced by the BCG vaccine was the major cytokine involved in blocking atopic disease in the lung. ${ }^{36}$ Mycobacterium vaccae is ubiquitously present in the soil as a saprophyte and can evoke a strong production of IFN- $\gamma$. Suppression of $\mathrm{T}_{\mathrm{H} 2}$ activation has been demonstrated using heat-killed $M$. vaccae in mice. ${ }^{38-40}$

The cytosine-guanosine dinucleotide repeat, when present in a particular base context, is known as a CpG motif and is an important prokaryotic immunomodulatory effector whose role is probably that of a warning or priming agent against bacterial infection. ${ }^{41}$ This motif is expressed at very low frequency in vertebrates, in a non-functional methylated form, and hence is without function. CpG vaccination directly induces antigen-presenting cells and B-lymphocytes to release IL-12, IL-18 and TNF $\gamma$ effectively, suppressing $\mathrm{T}_{\mathrm{H} 2}$ responses by inducing the $\mathrm{T}_{\mathrm{H} 1}$ phenotype. These $\mathrm{CpG}$ oligodinucleotides (ODN) prevent the development of eosinophilic airway inflammation, allergen-induced elevation of serum IgE and bronchial hyper-responsiveness in murine asthma models, ${ }^{42}$ and can also reduce established inflammation. ${ }^{42-44}$ The protective effects of CpG-ODN appear to be due to an induction of IL-12 and IFN- $\gamma \cdot{ }^{42,45}$ Other mechanisms may also be involved. ${ }^{46}$

\section{Specific cytokine profiles}

\section{Interleukin-10}

\section{Synthesis and release.}

IL-10, previously known as cytokine synthesis inhibitor factor (CSIF), was originally identified as a product of murine $\mathrm{T}$ helper $\left(\mathrm{T}_{\mathrm{H} 2}\right)$ clones that suppressed the production of cytokines by $\mathrm{T}_{\mathrm{H} 1}$ clones responding to stimulation of antigen. ${ }^{47}$ In humans, $\mathrm{T}_{\mathrm{H} 0}, \mathrm{~T}_{\mathrm{H} 1}$, and $\mathrm{T}_{\mathrm{H} 2}$-like $\mathrm{CD}^{+} \mathrm{T}$ cell clones, cytotoxic T-cells, activated monocytes and peripheral blood $\mathrm{T}$ cells including $\mathrm{CD}^{+}$and $\mathrm{CD}^{+}$T-cells have the capacity to produce IL-10. ${ }^{48,49}$ An autocrine action of IL-10 with increased production of IL-10 by antigenspecific cells may be responsible for the induction of anergy. ${ }^{31}$ Mast cells also have the capacity to produce IL-10. Constitutive IL-10 secretion occurs in the healthy lung with the major source being the alveolar macrophage; however, the circulating monocyte elaborates more IL-10 than the alveolar macrophage. ${ }^{50}$

\section{Receptors and signalling patbways.}

IL-10R has been characterised and cloned from a human lymphoma cell line, ${ }^{51}$ and is expressed in several lymphoid and myeloid cells, ${ }^{52}$ and also on NK cells. ${ }^{53}$ The IL-10R is made up of 2 subunits, which belong to the same class of receptor family that also contains receptors for IFN- $\gamma .{ }^{54}$ The IL-10 receptor $\alpha$-chain $(110 \mathrm{kDa})$ mediates high-affinity ligand binding and signal transduction, ${ }^{51,55}$ while the $\beta$ subunit $(40 \mathrm{kDa})$ is required for signalling. ${ }^{56}$ The functional IL$10 \mathrm{R}$ complex is a tetramer consisting of 2 IL-10 $\alpha$-chains and 2 IL-10 $\beta$-chains. Activation of IL-10R leads to the activation of JAK-STAT signalling pathway, with activation of JAK- 1 by the $\alpha$ chain and TYK 2 by the $\beta$ chain. These kinases then phosphorylate specific tyrosine residues on the intracellular domain of the IL-10R $\alpha$ chain. Once phosphorylated, these tyrosine residues serve as temporary docking sites for the latent transcription factors STAT1, STAT3 and STAT5. ${ }^{57,58}$ STAT3 is directly recruited to the IL-10R $\alpha$ and becomes phosphorylated by receptor-associated JAK kinases. STAT1 is also activated in macrophages. Upon phosphorylation, STAT1 and STAT3 homo/ heterodimerise and translocate to the nucleus where they bind with high affinity to STAT-binding elements in the promoters of various IL-10-responsive genes. One of these genes, SOCS-3 (suppressor of cytokine signalling-3) is a member of a newly identified family of genes that inhibit JAK/STAT-dependent signalling. The ability of IL-10 to inhibit gene expression in monocytes is associated with its ability to rapidly induce the synthesis of SOCS-3.

\section{Effects.}

IL-10 is a pleiotropic cytokine that can exert either immunosuppressive or immunostimulatory effects on a variety of cell types. IL-10 is a potent inhibitor of monocyte/macrophage function, suppressing the production of a number of pro-inflammatory cytokines, including TNF- $\alpha$, IL-1 $\beta$, IL-6, MIP- $1 \alpha$ and IL-8, ${ }^{59-61}$ although the release of MCP-1 is increased. ${ }^{61}$ IL-10 inhibits monocyte MHC Class II, B7.1/B7.2 and CD23 expression and accessory cell function. Accessory signals mediated by $\mathrm{B} 7$ molecules through CD28 on the surface of T-cells are essential for T-cell activation. Expression of IL-10 by antigen-presenting cells may be an established pathway for the induction of antigenspecific tolerance, such as that to allergens. ${ }^{62}$ By contrast, IL-10 up-regulates the monocyte expression of IL-1ra, another antiinflammatory cytokine. ${ }^{63}$ IL-10 suppresses the synthesis of superoxide anions and NO by activated monocytes/macrophages. ${ }^{64}$ An IL-10 antibody enhances the release of cytokines from activated monocytes, suggesting that this cytokine may play an inhibitory role when the cell is stimulated. $^{60}$ IL-10 inhibits the stimulated release of RANTES and IL-8 from human airway smooth muscle cells in culture. ${ }^{65,66}$ 
IL-10 inhibits the production of IFN- $\gamma$ and IL-2 by $\mathrm{T}_{\mathrm{H} 1}$ lymphocytes, ${ }^{47}$ and IL- 4 and IL-5 production by $\mathrm{T}_{\mathrm{H} 2}$ cells by interfering with B7-CD28-dependent signals. ${ }^{67,68}$ IL-10 inhibits the proliferative $\mathrm{T}$ cell response in peripheral blood mononuclear cells to various antigens, and the superantigen staphyloccocal enterotoxin B. IL-10 selectively inhibits the anti-CD28 stimulated proliferation of purified CD45RO+ T cells. There is a constitutive association of CD28 with the IL-10 receptor, and IL-10 acts directly on the CD28 signalling pathway to inhibit CD28 tyrosine phosphorylation and binding to phosphatidylinositol 3-kinase. ${ }^{69}$ IL-10 also inhibits eosinophil survival and IgE synthesis induced by IFN- $\gamma$. On the other hand, IL10 acts on B-cells to enhance their viability, cell proliferation, immunoglobulin secretion with the isotype switch and class II MHC expression. IL-10 decreases IL-4-induced IgE switch in peripheral blood mononuclear cells, but potentiates IgE production in B-cells that are already switched to produce IgE. ${ }^{70} \mathrm{IL}$ 10 is also a growth co-stimulator for thymocytes and mast cells, ${ }^{71}$ as well as an enhancer of cytotoxic T cell development. ${ }^{72}$ IL-10 increases Bcl-2 expression and survival of primary human CD34+ progenitor cells committed to the myeloid lineage. ${ }^{73}$ IL-10 also activates the transcription of genes for mast-cell derived proteases. IL-10 enhances the production of the tissue inhibitor of metalloproteinases of monocytes and tissue macrophages while decreasing metalloproteinase biosynthesis. ${ }^{74}$

\section{Role in allergy and astbma.}

There is significantly less IL-10 mRNA and protein expressed in alveolar macrophages of asthmatic subjects compared to those from non-asthmatic individuals. $^{75,76}$ Triggering of CD23 molecule by antiCD23 monoclonal antibodies induces IL-10 production by human monocytes. ${ }^{77}$ An IL-10 polymorphism on the transcription initiation site could be responsible for reduced IL-10 release. ${ }^{75}$ Another polymorphism upstream from this site was associated with elevated total serum IgE. $^{78}$ Inhaled corticosteroid therapy restores the reduced IL-10 release from macrophages of asthmatics ${ }^{76}$ and theophylline increases IL-10 secretion. ${ }^{79}$ On the other hand, other studies indicate that there are increased number of macrophages and T-cells expressing IL-10 mRNA in bronchoalveolar lavage fluid of patients with asthma. ${ }^{80}$

Studies regarding the role of IL-10 in allergic mouse models have provided some conflicting results. Coinstillation of IL-10 by the intranasal route significantly inhibits the peritoneal and lung eosinophilia induced by ovalbumin in immunised mice $;^{81-83}$ however, IL-10 augmented airway responsiveness. Concurrent expression of IL-10 and GM-CSF in the airway epithelium led to a suppression of GM-CSF-driven ovalbumin-specific eosinophilic inflammation with decreased IL-4, IL-5 and TNF $\gamma$ expression. However, in
IL-10 gene knock-out mice, allergen-induced eosinophilic inflammation, IL-5 production and airway hyper-responsiveness were inhibited. ${ }^{84-86}$ These studies in mice indicate that IL-10 may augment or decrease allergic inflammatory responses, but could worsen airway responsiveness.

IL-10 is involved in the induction of specific anergy in peripheral $\mathrm{T}$ cells during specific immunotherapy, characterised by suppressed proliferative and cytokine responses. IL-10 administration before allergen exposure induces antigen-specific $\mathrm{T}$ cell tolerance. ${ }^{31}$ IL-10-derived regulatory $\mathrm{CD}^{+}{ }^{+} \mathrm{T}$ cells producing IL-10 but not IL- 2 and IL- 4 suppresses antigen-specific $\mathrm{T}$ cell response in vitro and prevented antigen-induced murine colitis. ${ }^{87}$ Administration of IL-10 to normal volunteers induced a fall in circulating CD2, CD3, CD4 and CD8 lymphocytes with suppression of mitogen-induced T-cell proliferation and reductions in TNF- $\alpha$ and IL-1 $\beta$ production from whole blood stimulated with endotoxin ex-vivo. ${ }^{88}$

\section{Interferon- $\gamma$}

\section{Synthesis and release.}

IFN- $\gamma$ was originally identified as a product of mitogen-stimulated $\mathrm{T}$ lymphocytes that inhibited viral replication in fibroblasts. The known sources of IFN- $\gamma$ are $\mathrm{CD}^{+}$and $\mathrm{CD8}^{+}$T-cells and NK cells.

\section{Receptors and signalling.}

The receptor is expressed on T-cells, B-cells, monocytes/macrophages, dendritic cells, granulocytes and platelets. Epithelial and endothelial cells also express these receptors. IFN- $\gamma$ receptor consists of an $\alpha$-chain (90 kDa) which is the major ligand binding subunit, and of a $\beta$ chain $(65 \mathrm{kDa})$ which increases the affinity of the $\alpha$ chain for its ligand, but is obligatory for transducing the IFN- $\gamma$ signal. ${ }^{89,90}$ Signalling through the IFN- $\gamma$ receptor is mediated through JAK1 and JAK2, which are constitutively associated with specific membrane proximal residues on the cytoplasmic domain of the receptor. ${ }^{91,92}$ Activated JAKs phosphorylate a specific tyrosine residue, to which STAT-1 binds through its $\mathrm{SH} 2$ domain. ${ }^{93}$ STAT-1 is in turn phosphorylated by receptor-associated JAKs and homodimerisation of 2 STAT-1 proteins form a protein complex, GAF (gamma-activated factor). ${ }^{94}$ STAT-1 homodimer translocates to the nucleus where it binds to a consensus sequence leading to modulation of the expression of many genes. The recently identified SOCS (suppressors of cytokine signalling) family of proteins inhibits IFN- $\gamma$ signalling through the prevention of JAK kinase activation. ${ }^{95}$

\section{Effects.}

IFN- $\gamma$ has extensive and diverse immunoregulatory effects on various cells. It is produced by $\mathrm{T}_{\mathrm{H} 1}$-cells and exerts an inhibitory effect on $\mathrm{T}_{\mathrm{H} 2}$-cells. ${ }^{96}$ IFN- $\gamma$ 
inhibits antigen-induced eosinophil recruitment in the mouse. ${ }^{97}$ However, IFN- $\gamma$ may also have proinflammatory effects and may activate airway epithelial cells to release cytokines and express adhesion molecules. ${ }^{98}$ IFN- $\gamma$ has an amplifying effect on the release of TNF- $\alpha$ from alveolar macrophages induced by IgE triggering or by endotoxin ${ }^{99,100}$ and increases the expression of class I and class II MHC molecules on macrophages and epithelial cells. IFN- $\gamma$ is a powerful and relatively specific inhibitor of IL4-induced IgE and IgG4 synthesis by B-cells.

IFN- $\gamma$ increases the production of IL-1, PAF and $\mathrm{H}_{2} \mathrm{O}_{2}$ from monocytes, in addition to down-regulating IL-2-induced IL-8 mRNA expression. ${ }^{101-103}$ IFN- $\gamma$ also synergises the effects of TNF- $\alpha$ in the production of RANTES from airway smooth muscle cells. ${ }^{65}$ On the other hand, IFN- $\gamma$ inhibits IL-10 production from monocytes, ${ }^{104}$ which in turn leads to an upregulation of TNF- $\alpha$ transcription. ${ }^{105}$ Thus, IFN- $\gamma$ promotes cell-mediated cytotoxic responses, while inhibiting allergic inflammation and IgE synthesis. IFN- $\gamma$ up-regulates class II molecules on monocytes/ macrophages and dendritic cells, and induces de novo expression on epithelial, endothelial and other cells, thus making them capable of antigen presentation.

\section{Role in allergy and astbma.}

There is reduced production of IFN- $\gamma$ by T-cells of asthmatic patients and this correlates with disease severity. ${ }^{106,107}$ No polymorphism of the IFN- $\gamma$ gene has been associated with asthma. ${ }^{108}$ Administration of exogenous IFN- $\gamma$ prevents the airway eosinophilia and hyper-responsiveness following allergen exposure in mice. ${ }^{109,110}$ Liposome-mediated gene transfer of IFN- $\gamma$ to the pulmonary epithelium in sensitised mice before secondary antigen exposure also inhibited the pulmonary allergic response. ${ }^{111}$ IFN- $\gamma$ receptor knock-out mice develop a prolonged airway eosinophilia in response to allergen. ${ }^{112}$ IFN- $\gamma$ inhibits allergic eosinophilia ${ }^{109,113}$ and airway hyper-responsiveness, probably by inducing the formation of IL-10. These studies indicate that IFN- $\gamma$ has a potential modulating effect on allergen responses. The inhibition of the effects of allergen-specific $\mathrm{T}_{\mathrm{H} 2}$ cells, such as eosinophilia, mucus goblet cell hyperplasia and bronchial hyper-responsiveness, by allergen-specific $\mathrm{T}_{\mathrm{H} 1}$ cells is mediated by IFN- $\gamma \cdot{ }^{11,12}$ Allergen immunotherapy of asthmatic patients results in increased production of IFN- $\gamma$ by circulating T-cells ${ }^{114}$ and in an increase in IFN- $\gamma$ producing T-cells in nasal biopsies. ${ }^{115}$ Corticosteroid treatment also increases IFN- $\gamma$ expression in asthmatic airways, ${ }^{116}$ but in corticosteroid-resistant patients IFN- $\gamma$ is unexpectedly reduced. ${ }^{17}$ In asthmatic patients, nebulised IFN- $\gamma$ reduces the number of eosinophils in bronchoalveolar lavage, indicating its therapeutic potential in asthma. $^{118}$

\section{Interleukin-12}

\section{Synthesis and release.}

IL-12 was initially recognised as a cytokine capable of synergising with IL-2 to increase cytotoxic T-lymphocyte responses, and also as an inducer of IFN- $\gamma$ synthesis by resting human peripheral blood mononuclear cells in vitro. IL-12 is secreted by antigen-presenting cells, including B lymphocytes, monocytes/macrophages and dendritic cells. ${ }^{119,120} \mathrm{IL}-$ 12 mRNA has been localised to eosinophils in bronchoalveolar lavage fluid and in peripheral blood. $^{121}$

\section{Receptors and signalling.}

The IL-12 receptor is composed of two subunits ( $\beta 1$ and $\beta 2$ ), which are members of the haemopoietin receptor superfamily with strong homology to the gp130 receptor. ${ }^{122}$ The $\beta 1$ receptor is not able to transduce an IL-12-mediated signal, while the $\beta 2$ subunit when co-expressed with the $\beta 1$ subunit forms a high-affinity receptor for IL-12 and results in signalling. ${ }^{123}$ IL-12R $\beta 2$ expression is differentially regulated in $\mathrm{T}_{\mathrm{H} 1}$ as opposed to $\mathrm{T}_{\mathrm{H} 2}$ cells, ${ }^{124}$ while $\mathrm{T}_{\mathrm{H} 1}$ cells but not $\mathrm{T}_{\mathrm{H} 2}$ cells express the $\beta 2$ subunit. ${ }^{125}$ On binding of IL-12 to IL-12R, activation of JAK kinases occurs, leading to phosphorylation of the receptor, which become binding sites for STATs that are rapidly recruited to the receptor and tyrosine-phosphorylated by JAK kinases. Tyrosine phosphorylation of STAT proteins induces their dimerisation and translocation to the nucleus where they bind to specific sequences and regulate transcription. IL-12 stimulation causes TYK2 and JAK2 phosphorylation, and interaction of TYK2 with IL-12R $\beta 1$ subunit and interaction of JAK2 with the IL-12R $\beta 1$ subunit. ${ }^{126,127}$ In $\mathrm{T}_{\mathrm{H} 1}$ cells and NK cells, IL-12 induces STAT 4 to be tyrosine phosphorylated and activated. ${ }^{126,128}$ STAT1, STAT3 and STAT5 can also be activated by IL$12 .^{128,129}$

\section{Effects.}

IL-12 enhances the growth of activatedT-cells and NK cells ${ }^{130-133}$ and enhances cytotoxic T-cell and NK activity. ${ }^{130,134,135}$ IL-12 stimulates NK cells and T-cells to produce IFN- $\gamma$, 134,136-138 promotes in vitro differentiation of mouse and human T-cells that secrete IFN- $\gamma$ and TNF- $\alpha,{ }^{132,136,139,140}$ and inhibits the differentiation of T cells into IL- 4 secreting cells. ${ }^{139,140}$ IL-12 indirectly inhibits IL-4-induced human IgE responses by IFN- $\gamma$-dependent and -independent mechanisms in vitro. ${ }^{141}$ Thus, IL-12 can primarily regulate $\mathrm{T}_{\mathrm{H} 1}$ cell differentiation, while suppressing the expansion of $\mathrm{T}_{\mathrm{H} 2}$ cell clones, ${ }^{139}$ by early priming of undifferentiated $\mathrm{T}_{\mathrm{H}}$ cells for IFN- $\gamma$ secretion. ${ }^{142}$ Together with IL-18, IL-12 induces anti-CD40 activated $B$ cells to produce IFN- $\gamma$, which inhibits IL- 4 dependent IgE production. ${ }^{143}$ Thus, IL-12 may direct 
the development of $\mathrm{T}_{\mathrm{H} 1}$-like T-cell responses against intracellular pathogens, whilst inhibiting the development of $\mathrm{T}_{\mathrm{H} 2}$-like responses and IgE synthesis. IL-12 may also regulate airway eosinophilia. ${ }^{144}$ IL-12 may play an important role in inhibiting inappropriate IgE synthesis and allergic inflammation as a result of allergen exposure.

\section{Role in allergy and asthma.}

A decreased number of IL-12 mRNA positive cells in airway mucosal biopsies from patients with asthma has been reported. ${ }^{145}$ Corticosteroid treatment led to a reduction in the number of IL-12 mRNA expressing cells in steroid-sensitive asthmatics, but had no effect in steroid-resistant asthmatics. ${ }^{145}$ IL-12 production from whole blood cultures from patients with allergic asthma was reduced when compared to those from nonatopic control subjects, together with a reduction in IL-12-dependent IFN- $\gamma$ production. ${ }^{146}$ Similarly, the percentage of peripheral blood eosinophils from asthmatic subjects expressing IL-12 mRNA was lower compared to nonatopic controls. ${ }^{121}$

IL-12 may play an important role in inhibiting inappropriate IgE synthesis and allergic inflammation as a result of allergen exposure. Thus, IL-12 treatment of mice during active sensitisation reduced antigeninduced influx of eosinophils in bronchoalveolar lavage fluid, inhibited IgE synthesis, and abolished antigen-induced bronchial hyperresponsiveness. ${ }^{147}$ Once an inflammatory response is established, IL-12 inhibits antigen-induced bronchial hyperresponsiveness and inflammation. ${ }^{148}$ These effects of IL-12 are largely mediated by IFN- $\gamma .{ }^{149}$ In mice, IL-12 administered at the time of allergic sensitisation decreased specific IgE, tracheal ring responsiveness to acetylcholine and eosinophilia in bronchoalveolar lavage fluid after allergen challenge, together with IL-5 and IL-10 down-regulation; IL-12 administered after sensitisation did not alter specific IgE levels, had little effect on tracheal ring responsiveness and only a modest effect on the recruitment of eosinophils. ${ }^{150}$ Similarly, in a murine model of house dust mite (Der $\mathrm{p}$ 1) sensitisation, IL-12 during the sensitisation period increased Der $\mathrm{p}$ 1-specific serum IgG2a while decreasing the levels of IgG1 and IgE antibodies following multiple allergen challenges, together with downregulation of IL-5 production, without affecting eosinophilia; IL-12 administration after active sensitisation down-regulated IL-5 production, increased IFN$\gamma$ production, and abolished recruitment of eosinophils. ${ }^{151}$ Thus, the effect of IL-12 was dependent on the timing of its administration in relation to active sensitisation.

Mucosal gene transfer of IL-12 to the lungs prevented the development of allergic sensitisation and airways hyper-responsiveness dependent on IFN- $\gamma$ expression and suppressed established allergic disease, and reversed the suppression of local antiviral cell mediated immunity responses to vaccinia virus resulting in rapid resolution of virus infection. ${ }^{152}$ Similarly, concurrent expression of IL-12 and GM-CSF in the airway led to inhibition of GM-CSF enhancement of ovalbumin-induced effects in the mouse, namely ovalbumin-specific IgE synthesis and airway eosinophilia, partly due to the expression of IFN- $\gamma .{ }^{153}$ In another study, the suppressive effect of IL-12 on antigen-specific $\mathrm{T}_{\mathrm{H} 2}$-like cell development, IgE upregulation, airway hyperresponsiveness and eosinophilia in bronchoalveolar lavage fluid in an allergensensitised mouse model was only observed in combination with IL-18. ${ }^{154}$ In mild allergic atopic asthmatics, IL-12 caused a reduction in allergeninduced blood eosinophilia, but did inhibit allergeninduced late phase responses.

The production of IL-12 and of IL-12-induced IFN- $\gamma$ release is reduced in whole blood cultures from patients with allergic asthma compared to normal subjects. ${ }^{155}$ There is a reduction of IL-12 mRNA expression in airway biopsies of patients with allergic asthma compared to normal subjects, but following oral corticosteroid treatment, the levels of IL-12 mRNA increased in corticosteroid-sensitive asthmatics, while no significant changes were observed in corticosteroid-resistant asthmatics. ${ }^{145}$ This contrasts with the inhibitory effects of corticosteroids on IL-12 production in human monocytes in vitro. ${ }^{156}$ Allergen immunotherapy results in an increase in IL-12 expression. ${ }^{34} \mathrm{PGE}_{2}, \beta_{2}$-agonists and corticosteroids inhibit IL-12 production from monocytes. ${ }^{156-158}$

\section{References}

1. Djukanovic R, Roche WR, Wilson JW, Beasley CRW, Twentyman OP, Howarth PH. Mucosal inflammation in asthma. Am Rev Respir Dis 1990; 142: 434-457.

2. Azzawi M, Bradley B, Jeffery PK, Frew AJ, et al. Identification of activated Tymphocytes and eosinophils in bronchial biopsies in stable atopic asthma. Am Rev Respir Dis 1990; 142: 1407-1413.

3. Bousquet J, Chanez P, Lacoste JY, et al. Eosinophilic inflammation in asthma. $N$ Eng J Med 1990; 323: 1033-1039.

4. Bousquet J, Jeffery PK, Busse WW, Johnson M, Vignola AM. Asthma. From bronchoconstriction to airways inflammation and remodeling. Am J Respir Crit Care Med 2000; 161: 1720-1745.

5. Redington AE, Howarth PH. Airway wall remodelling in asthma [editorial]. Thorax 1997; 52: 310-312.

6. Chung KF, Barnes PJ. Cytokines in asthma [see comments]. Thorax 1999; 54: 825-857.

7. Green JM. The B7/CD28/CTLA4 T-cell activation pathway. Implications for inflammatory lung disease. Am J Respir Cell Mol Biol 2000; 22 261-264.

8. Harding FA, McArthur JG, Gross JA, Raulet DH, Allison JP. CD28mediated signalling co-stimulates murine $\mathrm{T}$ cells and prevents induction of anergy in T-cell clones. Nature 1992; 356: 607-609.

9. Walunas TL, Lenschow DJ, Bakker CY, et al. CTLA-4 can function as a negative regulator of $\mathrm{T}$ cell activation. Immunity 1994; 1: 405-413.

10. Oosterwegel MA, Mandelbrot DA, Boyd SD, et al. The role of CTLA-4 in regulating $\mathrm{T}_{\mathrm{H} 2}$ differentiation. J Immunol 1999; 163: 2634-2639.

11. Huang T-J, MacAry $\mathrm{P}$, Eynott $\mathrm{P}$, et al. Allergen-specific Th1 cells counteract effecrent Th2 cell-dependent bronchial hyperresponsiveness and eosinophilic inflammation, partly via IFN- $\gamma$. J Immunol 2001; 166: $207-217$.

12. Cohn L, Homer RJ, Niu N, Bottomly K. T helper 1 cells and interferon gamma regulate allergic airway inflammation and mucus production. $J$ Exp.Med 1999; 190: 1309-1318.

13. Prescott SL, Macaubas C, Smallacombe T, Holt BJ, Sly PD, Holt PG Development of allergen-specific T-cell memory in atopic and normal children [see comments]. Lancet 1999; 353: 196-200. 
14. Prescott SL, Macaubas C, Holt BJ, et al. Transplacental priming of the human immune system to environmental allergens: universal skewing of initial T cell responses toward the Th2 cytokine profile. J Immunol 1998; 160: 4730-4737.

15. Shirakawa T, Enomoto T, Shimazu S, Hopkin JM. The inverse association between tuberculin responses and atopic disorder [see comments] Science 1997; 275: 77-79.

16. Matricardi PM, Rosmini F, Rapicetta M, Gasbarrini G, Stroffolini T. Atopy, hygiene, and anthroposophic lifestyle. San Marino Study Group [letter] Lancet 1999; 354: 430 .

17. Gerrard JW, Geddes CA, Reggin PL, Gerrard CD, Horne S. Serum IgE levels in white and metis communities in Saskatchewan. Ann Allergy 1976; 37: 91-100.

18. Gustafsson D, Andersson K, Fagerlund I, Kjellman NI. Significance of indoor environment for the development of allergic symptoms in children followed up to 18 months of age. Allergy 1996; 51: 789-795.

19. van HA, van der Cammen MJ, Cooper D, Savelkoul HF, Kraal G, Holt PG Regulation of antigen-specific IgE, IgG1, and mast cell responses to ingested allergen by mucosal tolerance induction. J Immunol 1997; 159: 3009-3015.

20. Holt PG. Primary allergic sensitization to environmental antigens perinatal $\mathrm{T}$ cell priming as a determinant of responder phenotype in adulthood [comment]. J Exp.Med 1996; 183: 1297-1301.

21. Muller U, Akdis CA, Fricker M, et al. Successful immunotherapy with T-cell epitope peptides of bee venom phospholipase A2 induces specific T-cell anergy in patients allergic to bee venom. J Allergy Clin Immunol 1998; 101: 747-754.

22. Bousquet J, Lockey R, Malling HJ. Allergen immunotherapy: therapeutic vaccines for allergic diseases. A WHO position paper. $J$ Allergy Clin Immunol 1998; 102: 558-562.

23. Abramson M, Puy R, Weiner J. Immunotherapy in asthma: an updated systematic review. Allergy 1999; 54: 1022-1041.

24. Durham SR, Walker SM, Varga EM, et al. Long-term clinical efficacy of grass-pollen immunotherapy [see comments]. N.Engl.J Med 1999; 341 468-475.

25. Jutel M, Pichler WJ, Skrbic D, Urwyler A, Dahinden C, Muller UR. Bee venom immunotherapy results in decrease of IL- 4 and IL- 5 and increase of IFN-gamma secretion in specific allergen-stimulated $\mathrm{T}$ cell cultures. J.Immunol. 1995; 154: 4187-4194.

26. Secrist H, Chelen CJ, Wen Y, Marshall JD, Umetsu DT. Allergen immunotherapy decreases interleukin 4 production in $\mathrm{CD}^{+} \mathrm{T}$ cells from allergic individuals. J Exp.Med 1993; 178 2123-2130.

27. Bellinghausen I, Metz G, Enk AH, Christmann S, Knop J, Saloga J. Insect venom immunotherapy induces interleukin-10 production and a Th2-toTh1 shift, and changes surface marker expression in venom-allergic subjects. Eur J Immunol 1997; 27: 1131-1139.

28. Akdis CA, Blaser K. Mechanisms of allergen-specific immunotherapy [In Process Citation]. Allergy 2000; 55: 522-530.

29. Akdis CA, Blesken T, Akdis M, Wuthrich B, Blaser K. Role of interleukin 10 in specific immunotherapy. J Clin Invest. 1998; 102: 98-106.

30. Becker JC, Czerny C, Brocker EB. Maintenance of clonal anergy by endogenously produced IL-10. Int.Immunol 1994; 6: 1605-1612.

31. Enk AH, Saloga J, Becker D, Madzadeh M, Knop J. Induction of haptenspecific tolerance by interleukin 10 in vivo. J Exp.Med 1994; 179 1397-1402.

32. Del Prete G, DeCarliM, Almerigogna F, Giudizi MG, Biagiotti R, Romagnani S. Human IL-10 is produced by both type 1 helper (Th1) and type 2 helper (Th2) T cell clones and inhibits their antigen-specific proliferation and cytokine production. J Immunol 1993; 150 353-360.

33. Punnonen J, de Waal Malefyt R, van Vlasselaer P, Gauchat JF, De Vries JE IL-10 and viral IL-10 prevent IL-4-induced IgE synthesis by inhibiting the accessory cell function of monocytes. J Immunol 1993; 151: 1280-1289.

34. Hamid QA, Schotman E, Jacobson MR, Walker SM, Durham SR Increases in IL-12 messenger RNA+ cells accompany inhibition of allergen-induced late skin responses after successful grass pollen immunotherapy [see comments]. J Allergy Clin Immunol 1997; 99 254-260.

35. Durham SR, Ying S, Varney VA, et al. Grass pollen immunotherapy inhibits allergen-induced infiltration of CD4+ T lymphocytes and eosinophils in the nasal mucosa and increases the number of cells expressing messenger RNA for interferon-gamma. J Allergy Clin Immunol. 1996; 97: 1356-1365.

36. Erb KJ, Holloway JW, Sobeck A, Moll H, Le Gros G. Infection of mice with Mycobacterium bovis-Bacillus Calmette-Guerin (BCG) suppresse allergen-induced airway eosinophilia. J Exp Med 1998; 187: 561-569

37. Herz U, Gerhold K, Gruber C, et al. BCG infection suppresses allergic sensitization and development of increased airway reactivity in an animal model. J Allergy Clin Immunol 1998; 102: 867-874.

38. Camporota L, Corkhill A, Long $\mathrm{H}$, et al. Effects of intradermal injection of SRL-172 (killed Mycobacterium vaccae suspension) on allergeninduced airway responses and IL-5 generation by PBMC in asthma. $A m$ J Respir Crit Care Med 2000; 161: A477(Abstract).
39. McMillan S, Escott K, Webber S, FosterM Sargant C. Effect of heat-killed Mycobacterium vaccae on murine antigen induced airway inflammation. Am J Respir Crit Care Med 2000; 161: A477(Abstract).

40. Wang CC, Rook GA. Inhibition of an established allergic response to ovalbumin in BALB/c mice by killed Mycobacterium vaccae. Immunology 1998; 93: 307-313.

41. Krieg AM. An innate immune defense mechanism based on the recognition of CpG motifs in microbial DNA. J Lab Clin Med 1996; 128 : 128-133.

42. Kline JN, Waldschmidt TJ, Businga TR, et al. Modulation of airway inflammation by $\mathrm{CpG}$ oligodeoxynucleotides in a murine model of asthma. J Immunol 1998; 160: 2555-2559.

43. Broide D, Raz E. DNA-Based immunization for asthma. Int Arch Allergy Immunol 1999; 118: 453-456.

44. Serebrisky D, Tepper A, Kattan M, Sampson H, Li X-M. Systemic or local $\mathrm{CpG}$ administration inhibits ongoing allergic airway inflammation. $\mathrm{Am}$ J Resp Cell Mol Biol 2000; 161: A549(Abstract).

45. Broide $\mathrm{D}$, Schwarze $\mathrm{J}$, Tighe $\mathrm{H}$, et al. Immunostimulatory DNA sequences inhibit IL-5, eosinophilic inflammation, and airway hyperresponsiveness in mice. J Immunol 1998; 161: 7054-7062.

46. Kline JN, Krieg AM, Waldschmidt TJ, Ballas ZK, Jain V, Businga TR. CpG oligodeoxynucleotides do not require TH1 cytokines to prevent eosinophilic airway inflammation in a murine model of asthma. $J$ Allergy Clin Immunol 1999; 104: 1258-1264.

47. Fiorentino DF, Bond MW, Mosmann TR. Two types of mouse helper T cells. IV. Th 2 clones secrete a factor that inhibits cytokine production by Th 1 clones. J Exp Med 1989; 170: 2081-2081.

48. Enk AH, Katz SI. Identification and induction of keratinocyte-derived IL10. J Immunol 1992; 149: 92-95.

49. Spits H, de Waal Malefyt R. Functional characterization of human IL-10. Int Arch Allergy Appl Immunol 1992; 99: 9-15.

50. Berkman N, John M, Roesems G, Jose PJ, Barnes PJ, Chung KF. Inhibition of macrophage inflammatory protein- $1 \alpha$ by interleukin-10: Differential sensitivities in human blood monocytes and alveolar macrophages. $J$ Immunol 1995; 155: 4412-4418.

51. Liu Y, Wei SH, Ho AS, de Waal Malefyt R, Moore KW. Expression cloning and characterization of a human IL-10 receptor. J Immunol 1994; 152 1821-1829.

52. Tan JC, Indelicato SR, Narula SK, Zavodny PJ, Chou CC. Characterization of interleukin-10 receptors on human and mouse cells. $J$ Biol Chem 1993; 268: 21053-21059.

53. Carson WE, Lindemann MJ, Baiocchi R, et al. The functional character ization of interleukin-10 receptor expression on human natural killer cells. Blood 1995; 85: 3577-3585.

54. Bazan JF Structural design and molecular evolution of a cytokine receptor superfamily. Proc Natl Acad Sci USA 1990; 87: 6934-6938.

55. Ho AS, Liu Y, Khan TA, Hsu DH, Bazan JF, Moore KW. A receptor for interleukin 10 is related to interferon receptors. Proc Natl Acad Sci USA 1993; 90: 11267-11271.

56. Spencer SD, Di MF, Hooley J, et al. The orphan receptor CRF2-4 is an essential subunit of the interleukin 10 receptor. $J$ Exp Med 1998; 187: 571-578.

57. Finbloom DS, Winestock KD. IL-10 induces the tyrosine phosphorylation of tyk 2 and Jak 1 and the differential assembly of STAT 1 alpha and STAT3 complexes in human T cells and monocytes. J Immunol 1995; 155: 1079-1090.

58. Wehinger J, Gouilleux F, Groner B, Finke J, Mertelsmann R, Weber-Nord RM. IL-10 induces DNA binding activity of three STAT proteins (Stat1, Stat3, and Stat5) and their distinct combinatorial assembly in the promoters of selected genes. FEBS Lett 1996; 394: 365-370.

59. Fiorentino DF, Zlotnik A, Mossmann TR, Howard M, O'Garra A. IL-10 inhibits cytokine production by activated macrophages. $J$ Immunol 1991; 147: 3815-3822.

60. de Waal Malefyt R, Abrams J, Bennett B, Figdor CG, De Vries JE Interleukin 10 (IL-10) inhibits cytokine synthesis by human monocytes: an auto regulatory role of IL-10 produced by monocytes. J Exp Med 1991; 179: 1209-1220.

61. Seitz M, Loetscher P, Dewald B, Towbin H, Gallati H, Baggiolini M Interleukin-10 differentially regulates cytokine inhibitor and chemokine release from blood mononuclear cells and fibroblasts. Eur J Immunol 1995; 25: 1129-1132

62. Malefyt RdM, Haanen J, Spits H, et al. Interleukin 10 (IL-10) and viral IL 10 strongly reduce antigen-specific human $\mathrm{T}$ cell proliferation by diminishing the antigen-presenting capacity of monocytes via downregulation of class II major histocompatibility complex expression. $J$ Exp Med 1991; 174: 915-924.

63. de Waal Malefyt R, Yssel H, Roncarolo MG, Spits H, De Vries JE Interleukin-10. Curr Opin Immunol 1992; 4: 314-320.

64. Cunha FQ, Moncada S, Liew FY. Interleukin-10 (IL-10) inhibits the induction of nitric oxide synthase by interferon-gamma in murine macrophages. Biochem Biophys Res Commun 1992; 182 1155-1159.

65. John M, Hirst SJ, Jose PJ, et al. Human airway smooth muscle cells express and release RANTES in response to Th-1 cytokines: regulation by Th-2 cytokines and corticosteroids. J Immunol 1997; 158 $1841-1847$ 
66. John M, Au BT, Jose PJ, Lim S, Saunders M, Barnes PJ, Mitchell JA, Belvisi MG, Chung KF. Expression and release of interleukin-8 by human airway smooth muscle cells: inhibition by Th- 2 cytokines and corticosteroids. Am J Respir Cell Mol Biol 1998; 18; 84-90.

67. Moore KW, O'Garra A, de Waal Malefyt R, Vieira P, Mosmann TR. Interleukin-10. Annu Rev Immunol 1993; 11: 165-190.

68. Schandene L, Alonso Vega C, Willems F, et al. B7/CD28-dependent IL-5 production by human resting T cells is inhibited by IL-10. J Immunol 1994; 152: 4368-4374

69. Akdis CA, Joss A, Akdis M, Faith A, Blaser K. A molecular basis for T cell suppression by IL-10: CD28-associated IL-10 receptor inhibits CD28 tyrosine phosphorylation and phosphatidylinositol 3-kinase binding [In Process Citation]. FASEB J 2000; 14(12): 1666-1668.

70. Jeannin P, Lecoanet S, Delneste Y, Gauchat JF, Bonnefoy JY. IgE versus IgG4 production can be differentially regulated by IL-10. J Immunol 1998; 160: 3555-3561

71. Thompson-Snipes LA, Dhar V, Bond MW, Mosmann TR, Moore KW, Rennick DM. Interleukin 10: a novel stimulatory factor for mast cells and their progenitors. J Exp Med 1991; 173: 507-510.

72. Chen WF, Zlotnik A. IL-10:A novel cytotokic T cell differentiation factor. I Immunol 1991; 147: 520-534.

73. Weber-Nordt RM, Henschler R, Schott E, et al. Interleukin-10 increases $\mathrm{Bcl}-2$ expression and survival in primary human $\mathrm{CD} 34+$ hematopoietic progenitor cells. Blood 1996; 88: 2549-2558.

74. Lacraz S, Nicod LP, Chicheportiche R, Welgus HG, Dayer JM. IL-10 inhibits metalloproteinase and stimulates TIMP-1 production in human mononuclear phagocytes. J Clin Invest 1995; 96: 2304-2310.

75. Borish L, Aarons A, Rumbyrt J, Cvietusa P, Negri J, Wenzel S. Interleukin10 regulation in normal subjects and patients with asthma. $J$ Allergy Clin Immunol 1996; 97: 1288-1296.

76. John M, Lim S, Seybold J, et al. Inhaled corticosteroids increase interleukin-10 but reduce macrophage inflammatory protein-1a, granulocyte-macrophage colony-stimulating factor and interferon-Y release from alveolar macrophages in asthma. Amer J Respir Crit Care Med 1998; 157: 256-262

77. Dugas N, Vouldoukis I, Becherel P, et al. Triggering of CD23b antigen by anti-CD23 monoclonal antibodies induces interleukin-10 production by human macrophages. Eur J Immunol 1996; 26: 1394-1398.

78. Hobbs K, Negri J, Klinnert M, Rosenwasser LJ, Borish L. Interleukin-10 and transforming growth factor-beta promoter polymorphisms in allergies and asthma [In Process Citation]. Am J Respir Crit Care Med 1998; 158: 1958-1962.

79. Mascali JJ, Cvietusa P, Negri J, Borish L. Anti-inflammatory effects of theophylline: modulation of cytokine production. Ann Allergy Asthma Immunol 1996; 77: 34-38

80. Robinson DS, Tsicopoulos A, Meng Q, Durham S, Kay AB, Hamid Q. Increased interleukin-10 messenger RNA expression in atopic allergy and asthma. Am J Respir Cell Mol Biol 1996; 14: 113-117.

81. Zuany Amorim C, Creminon C, Nevers MC, Nahori MA, Vargaftig BB, Pretolani M. Modulation by IL-10 of antigen-induced IL-5 generation, and CD4+ T lymphocyte and eosinophil infiltration into the mouse peritoneal cavity. J Immunol 1996; 157: 377-384.

82. Zuany Amorim C, Haile S, Leduc D, et al. Interleukin-10 inhibits antigeninduced cellular recruitment into the airways of sensitized mice. J Clin Invest 1995; 95: 2644-2651.

83. van SM, Justice JP, Bradfield JF, Enright E, Sigounas A, Sur S. IL-10 reduces $T h 2$ cytokine production and eosinophilia but augments airway reactivity in allergic mice. Am J Physiol Lung Cell Mol Physiol 2000; 278: L667-L674.

84. Yang X, Wang S, Fan Y, Han X. IL-10 deficiency prevents IL-5 overproduction and eosinophilic inflammation in a murine model of asthma-like reaction. Eur J Immunol 2000; 30: 382-391.

85. Tournoy KG, Kips JC, Pauwels RA. Endogenous interleukin-10 suppresses allergen-induced airway inflammation and nonspecific airway responsiveness [see comments]. Clin Exp Allergy 2000; 30: $775-783$.

86. Makela MJ, Kanehiro A, Borish L, et al. IL-10 is necessary for the expression of airway hyper-responsiveness but not pulmonary inflammation after allergic sensitization. Proc Natl Acad Sci USA 2000; 97: 6007-6012.

87. Groux H, Bigler M, de VJ, Roncarolo MG. Interleukin-10 induces a longterm antigen-specific anergic state in human CD4+ $\mathrm{T}$ cells [see comments]. J Exp Med 1996; 184: 19-29.

88. Chernoff AE, Granowitz EV, Shapiro L, et al. A randomized, controlled trial of IL-10 in humans. Inhibition of inflammatory cytokine production and immune responses. J Immunol 1995; 154: 5492-5499.

89. Hemmi S, Bohni R, Stark G, Di MF, Aguet M. A novel member of the interferon receptor family complements functionality of the murine interferon gamma receptor in human cells. Cell 1994; 76: 803-810.

90. Marsters SA, Pennica D, Bach E, Schreiber RD, Ashkenazi A. Interferon gamma signals via a high-affinity multisubunit receptor complex that contains two types of polypeptide chain. Proc Natl Acad Sci USA 1995 ; 92: 5401-5405.

91. Igarashi K, Garotta G, Ozmen L, et al. Interferon-gamma induces tyrosine phosphorylation of interferon-gamma receptor and regulated association of protein tyrosine kinases, Jak1 and Jak2, with its receptor. J Biol Chem 1994; 269: 14333-14336.
92. Sakatsume M, Igarashi K, Winestock KD, Garotta G, LarnerAC, Finbloom DS. The Jak kinases differentially associate with the alpha and beta (accessory factor) chains of the interferon gamma receptor to form a functional receptor unit capable of activating STAT transcription factors. J Biol Chem. 1995; 270: 17528-17534.

93. Heim MH, Kerr IM, Stark GR, Darnell JEJ. Contribution of STAT SH2 groups to specific interferon signaling by the Jak-STAT pathway. Science 1995; 267: 1347-1349.

94. Decker T, Lew DJ, Mirkovitch J, Darnell JEJ. Cytoplasmic activation of GAF, an IFN-gamma-regulated DNA-binding factor. ЕMBO J 1991; 10: 927-932.

95. Sakamoto H, Yasukawa H, Masuhara M, et al. A Janus kinase inhibitor, $\mathrm{JAB}$, is an interferon-gamma-inducible gene and confers resistance to interferons. Blood 1998; 92: 1668-1676.

96. Romagniani S. Regulation and deregulation of human IgE synthesis. Immunol Today 1990; 11: 316-321.

97. Nakajima H, Iwamoto I, Yoshida S. Aerosolized recombinant interferongamma prevents antigen-induced eosinophil recruitment in mouse trachea. Am Rev Respir Dis 1993; 148: 1102-1104.

98. Look DC, Rapp SR, Keller BT, Holzman MJ. Selective induction of intracellular adhesion molecule-1 by interferon-gamma in human airway epithelial cells. Am J Physiol 1992; 263: L79-L87.

99. Gosset $\mathrm{P}$, Tsicopoulos A, Wallaert B, et al. Tumor necrosis factor a and interleukin-6 production by human mononuclear phagocytes from allergic asthmatics after IgE-dependent stimulation. Am Rev Respir Dis 1992; 146: 768-774.

100. Gifford GE, Lohmann-Matthess ML. Gamma interferon priming of mouse and human macrophages for induction of tumor necrosis factor production by bacterial lipopolysaccharide. J Natl Cancer Inst. 1987; 78: 121-124.

101. Billiau A, Dijkmans R. Interferon-gamma: machanism of action and therapeutic potential. [Review]. Biochem Pharmacol 1990; 40: 1433-1439.

102. Sen GC, Lenggel $P$. The interferon system: a bird's eye view of its biochemistry. J Biol Chem 1992; 267: 5017-5019.

103. Gusella GL, Musso T, Bosco MC, Espinoza-Delgado I, Matsushima K, Varesio L. IL-2 up-regulates but IFN- $\gamma$ suppresses IL-8 expression in human monocytes. J Immunol 1993; 151: 2725-2732.

104. Chomarat P, Rissoan MC, Banchereau J, Miossec P. Interferon gamma inhibits interleukin 10 production by monocytes. J Exp Med 1993; 177: 523-527.

105. Donnelly RP, Freeman SL, Hayes MP. Inhibition of IL-10 expression by IFN-gamma up-regulates transcription of TNF-alpha in human monocytes. I Immunol 1995; 155: 1420-1427.

106. Leonard C, Tormey V, Burke C, Poulter LW. Allergen-induced cytokine production in atopic disease and its relationship to disease severity. $\mathrm{Am}$ J Respir Cell Mol Biol 1997; 17: 368-375.

107. Koning H, Neijens HJ, Baert MR, Oranje AP, Savelkoul HF. T cell subsets and cytokines in allergic and non-allergic children. I. Analysis of IL-4, IFN-gamma and IL-13 mRNA expression and protein production. Cytokine 1997; 9: 416-426.

108. Hayden C, Pereira E, Rye $\mathrm{P}$, et al. Mutation screening of interferongamma (IFN-gamma) as a candidate gene for asthma. Clin Exp Allergy 1997; 27: 1412-1416.

109. Lack G, Bradley KL, Hamelmann E, et al. Nebulized IFN-gamma inhibits the development of secondary allergic responses in mice. $J$ Immunol 1996; 157: 1432-1439.

110. Iwamoto I, Nakajima H, Endo H, Yoshida S. Interferon gamma regulates antigen-induced eosinophil recruitment into the mouse airways by inhibiting the infiltration of CD4+ T cells. J Exp Med 1993; 177 573-576.

111. Li XM, Chopra RK, Chou TY, Schofield BH, Wills-KarpM, Huang SK. Mucosal IFN-g gene transfer inhibits allergic responses in mice. $J$ Immunol 1996; 157: 3216-3219.

112. Coyle AJ, Tsuyuki S, Bertrand C, et al. Mice lacking the IFN-gamma receptor have impaired ability to resolve a lung eosinophilic inflammatory response associated with a prolonged capacity of $\mathrm{T}$ cells to exhibit a Th2 cytokine profile. J Immunol 1996; 156: 2680-2685

113. Zuany Amorim C, Leduc D, Vargaftig BB, Pretolani M. Modulation by rm interferon-gamma and CD4+ T-lymphocytes of allergic eosinophil accumulation in the mice peritoneal cavity. Ann NY Acad Sci 1994; 725: $34-43$.

114. Lack G, Nelson HS, Amran D, et al. Rush immunotherapy results in allergen-specific alterations in lymphocyte function and interferongamma production in CD4+ T cells. J Allergy Clin Immunol 1997; 99 $530-538$.

115. Durham SR, Till SJ. Immunologic changes associated with allergen immunotherapy. J Allergy Clin Immunol 1998; 102: 157-164.

116. Bentley AM, Hamid Q, Robinson DS, et al. Prednisolone treatment in asthma. Reduction in the numbers of eosinophils, T cells, tryptase-only positive mast cells, and modulation of IL- $4, \mathrm{IL}-5$, and interferon-gamma cytokine gene expression within the bronchial mucosa. Am J Respir Crit Care Med 1996; 153: 551-556.

117. Leung DY, Martin RJ, Szefler SJ, et al. Dysregulation of interleukin 4 , interleukin 5, and interferon gamma gene expression in steroid-resistant asthma. Journal of Experimental Medicine 1995; 181: 33-40. 
118. BoguniewiczM, Martin RJ, Martin D, et al. The effects of nebulized recombinant interferon-gamma in asthmatic airways. J Allergy Clin Immunol 1995; 95: 133-135.

119. Trinchieri G. Interleukin-12: a proinflammatory cytokine with immunoregulatory functions that bridge innate resistance and antigenspecific adaptive immunity. [Review]. Annual Review of Immunology 1995; 13: 251-276.

120. Macatonia SE, Hosken NA, Litton M, et al. Dendritic cells produce IL-12 and direct the development of Th1 cells from naive CD4+ T cells. $J$ Immunol 1995; 154: 5071-5079.

121. Nutku E, Gounni AS, Olivenstein R, Hamid Q. Evidence for expression of eosinophil-associated IL-12 messenger RNA and immunoreactivity in bronchial asthma. J Allergy Clin Immunol 2000; 106: 288-292.

122. Chua AO, Chizzonite R, Desai BB, et al. Expression cloning of a human IL-12 receptor component. A new member of the cytokine receptor superfamily with strong homology to gp130. J Immunol 1994; 153 128-136.

123. Presky DH, Yang H, Minetti LJ, et al. A functional interleukin 12 receptor complex is composed of two beta-type cytokine receptor subunits. Proc Natl Acad Sci USA 1996; 93: 14002-14007.

124. Szabo SJ, Dighe AS, Gubler U, Murphy KM. Regulation of the interleukin (IL)-12R beta 2 subunit expression in developing T helper 1 (Th1) and Th2 cells. J Exp.Med 1997; 185: 817-824.

125. Rogge L, Barberis-Maino L, Biffi M, et al. Selective expression of an interleukin-12 receptor component by human T helper 1 cells. $J$ Exp Med 1997; 185: 825-831.

126. Bacon CM, McVicar DW, Ortaldo JR, Rees RC, O'Shea JJ, Johnston JA. Interleukin 12 (IL-12) induces tyrosine phosphorylation of JAK2 and TYK2: differential use of Janus family tyrosine kinases by IL- 2 and IL-12 Journal of Experimental Medicine 1995; 181: 399-404.

127. Zou J, Presky DH, Wu CY, Gubler U. Differential associations between the cytoplasmic regions of the interleukin-12 receptor subunits beta1 and beta2 and JAK kinases. J Biol Chem 1997; 272: 6073-6077.

128. Jacobson NG, Szabo SJ, Weber-Nordt RM, et al. Interleukin 12 signaling in T helper type 1 (Th1) cells involves tyrosine phosphorylation of signal transducer and activator of transcription (Stat)3 and Stat4. J Exp Med 1995; 181: 1755-1762.

129. Yu CR, Lin JX, Fink DW, Akira S, Bloom ET, Yamauchi A. Differential utilization of Janus kinase-signal transducer activator of transcription signaling pathways in the stimulation of human natural killer cells by IL2, IL-12, and IFN-alpha. J Immunol 1996; 157: 126-137.

130. Robertson MJ, Soiffer RJ, Wolf SF, et al. Responses of human natural killer (NK) cells to NK cell stimulatory factor (NKSF): cytolytic activity and proliferation of NK cells are differentially regulated by NKSF. $J$ Exp Med 1992; 175: 779-785.

131. Gately MK, Desai B, Wolitzky AG, et al Regulation of human lymphocyte proliferation by a heterodimeric cytokine, IL-12 (cytotoxic lymphocyte maturation factor). J Immunol 1991; 147: 874-879.

132. Perussia B, Chan SH, D'Andrea A, et al. Natural killer (NK) cell stimulatory factor or IL-12 has differential effects on the proliferation of TCR- $\alpha \beta+$, TCR- $\tau \delta+$ T lymphocytes, and NK cells. J Immunol 1992; 149: 3495-3499.

133. Bertagnolli MM, Lin B-Y, Young D, Herrmann SH. IL-12 augments antigen-dependent proliferation of activated T lymphocytes. J Immunol 1992; 149: 3778-3782

134. Kobayashi M, Fitz L, Ryan M, et al. Identification and purification of natural killer cell stimulatory factor (NKSF), a cytokine with multiple biological effects on human lymphocytes. J Exp Med 1989; 170: 827-832.

135. Gately MK, Wolitzky AG, Quinn PM, Chizzonite R. Regulation of human cytolytic lymphocyte responses by interleukin-12. Cell Immunol 1992; 143: $127-130$.

136. Chan SH, Perussia B, Gupta JW, et al. Induction of interferon $\tau$ production by natural killer cell stimulatory factor: characterization of the responder cells and synergy with other inducers. J Exp Med 1991; 173: 369-904.

137. Wolf SF, Temple PA, Koboyashi M, et al. Cloning of cDNA for natural killer cell stimulatory factor, a heterodimeric cytokine with multiple biologic effects on $\mathrm{T}$ and natural killer cells. J Immunol 1991; 146: 3074-3079.

138. Schoenhaut DS, Chua AO, Wolitzky AG, et al. Cloning and expression of murine IL-12.J Immunol 1992; 148: 3433-3437.

139. Manetti R, Parronchi P, Giudizi MG, et al. Natural killer cell stimulatory factor (interleukin 12 (IL-12) induces I helper type 1 (Th1)-specific immune responses and inhibits the development of IL-4-producing Th cells. J Exp Med 1993; 177: 1199-1204.
140. Hsieh C-S, Macatonia SE, Tripp CS, Wolf SF, O'Garra A, Murphy KM Development of T 1 CD4+ T cells through IL-12 produced by Listeriainduced macrophages. Science 1993; 260: 547-549.

141. Kiniwa M, Gately M, Gubler U, Chizzonite R, Fargeas C, Delespesse G. Recombinant interleukin-12 suppresses the synthesis of IgE by interleukin-4 stimulated human lymphocytes. J Clin Invest 1992; 90 262-266.

142. Manetti R, Gerosa F, Giudizi MG, et al. Interleukin 12 induces stable priming for interferon gamma (IFN-gamma) production during differentiation of human $\mathrm{T}$ helper (Th) cells and transient IFN-gamma production in established Th2 cell clones. J Exp Med 1994; 179: 1273-1283.

143. Yoshimoto T, Okamura H, Tagawa YI, Iwakura Y, Nakanishi K. Interleukin 18 together with interleukin 12 inhibits IgE production by induction of interferon-gamma production from activated B cells. Proc Natl Acad Sci USA 1997; 94: 3948-3953.

144. Zhao LL, Linden A, Sjostrand M, Cui ZH, Lotvall J, Jordana M. IL-12 regulates bone marrow eosinophilia and airway eotaxin levels induced by airway allergen exposure [In Process Citation]. Allergy 2000; 55: 749-756.

145. Naseer T, Minshall EM, Leung DY, et al. Expression of IL-12 and IL-13 mRNA in asthma and their modulation in response to steroid therapy. Am J Respir Crit Care Med 1997; 155: 845-851.

146. van der Pouw Kraan TC, Boeije LC, de GE, et al. Reduced production of IL-12 and IL-12-dependent IFN-gamma release in patients with allergic asthma. J Immunol 1997; 158: 5560-5565.

147. Kips JC, Brusselle GJ, Joos GF, et al. Interleukin-12 inhibits antigeninduced airway hyper-responsiveness in mice. Am J Respir Crit Care Med 1996; 153: 535-539.

148. Gavett SH, O'Hearn DJ, Li X, Huang SK, Finkelman FD, Wills Karp M. Interleukin 12 inhibits antigen-induced airway hyper-responsiveness inflammation, and Th2 cytokine expression in mice. J Exp Med 1995 182: $1527-1536$.

149. Bruselle GG, Kips JC, Peleman RA, et al. Role of IFN-gamma in the inhibition of the allergic airway inflammation caused by IL-12. Am J Respir Cell Mol Biol 1997; 17: 767-771.

150. Sur S, Lam J, Bouchard P, Sigounas A, Holbert D, Metzger WJ. Immunomodulatory effects of IL-12 on allergic lung inflammation depend on timing of doses. J Immunol 1996; 157: 4173-4180.

151. Lee $\mathrm{Y}, \mathrm{Fu} \mathrm{C}$, Chiang B. Administration of interleukin-12 exerts a therapeutic instead of a long-term preventive effect on mite Der p I allergen-induced animal model of airway inflammation. Immunology 1999; 97: 232-240.

152. Hogan SP, Foster PS, Tan X, Ramsay AJ. Mucosal IL-12 gene delivery inhibits allergic airways disease and restores local antiviral immunity. Eur J Immunol 1998; 28: 413-423.

153. Stampfli MR, Cwiartka M, Gajewska BU, et al. Interleukin-10 gene transfer to the airway regulates allergic mucosal sensitization in mice [see comments]. Am J Respir Cell Mol Biol 1999; 21: 586-596.

154. Hofstra CL, van Ark I, Hofman G, Kool M, Nijkamp FP, Van Oosterhout AJ. Prevention of Th2-like cell responses by coadministration of IL-12 and IL-18 is associated with inhibition of antigen-induced airway hyperresponsiveness, eosinophilia, and serum IgE levels. J Immunol 1998; 161: 5054-5060.

155. van der Pouw Kraan TC, Boeije LC, de Groot ER, et al. Reduced production of IL-12 and IL-12-dependent IFN-gamma release in patients with allergic asthma. J Immunol 1997; 158: 5560-5565.

156. Blotta MH, DeKruyff RH, Umetsu DT. Corticosteroids inhibit IL-12 production in human monocytes and enhance their capacity to induce IL-4 synthesis in CD4+ lymphocytes. J Immunol 1997; 158: 5589-5595.

157. van der Pouw Kraan TC, Boeije LC, Smeenk RJ, Wijdenes J, Aarden LA. Prostaglandin-E2 is a potent inhibitor of human interleukin 12 production. Journal of Experimental Medicine 1995; 181: 775-779.

158. Panina-Bordignon P, Mazzeo D, Lucia PD, et al. Beta2-agonists prevent Th1 development by selective inhibition of interleukin 12.J Clin Invest 1997; 100: 1513-1519.

Received November 2000; accepted January 2001 


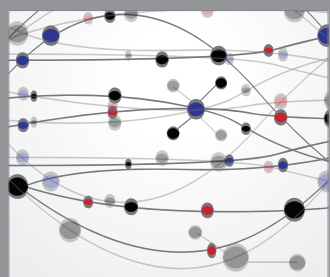

The Scientific World Journal
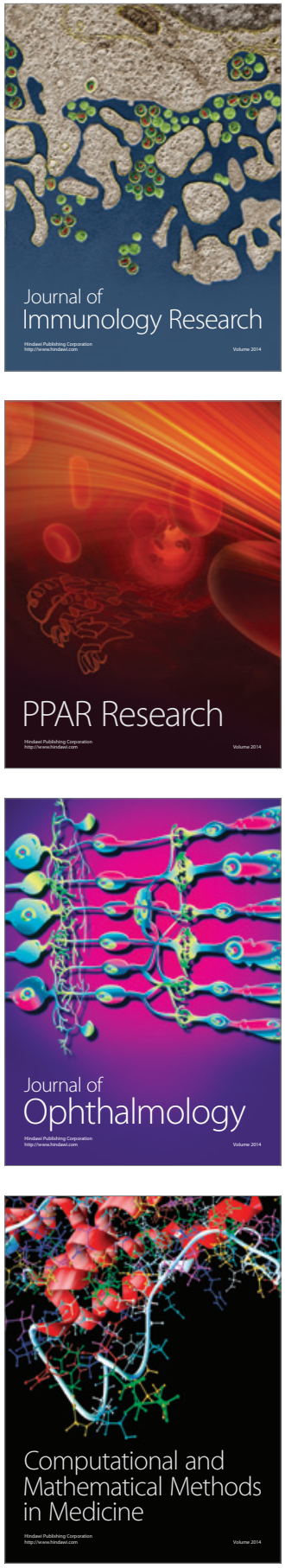

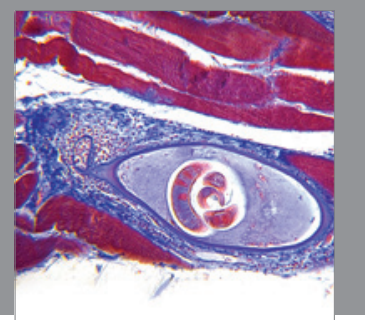

Gastroenterology

Research and Practice
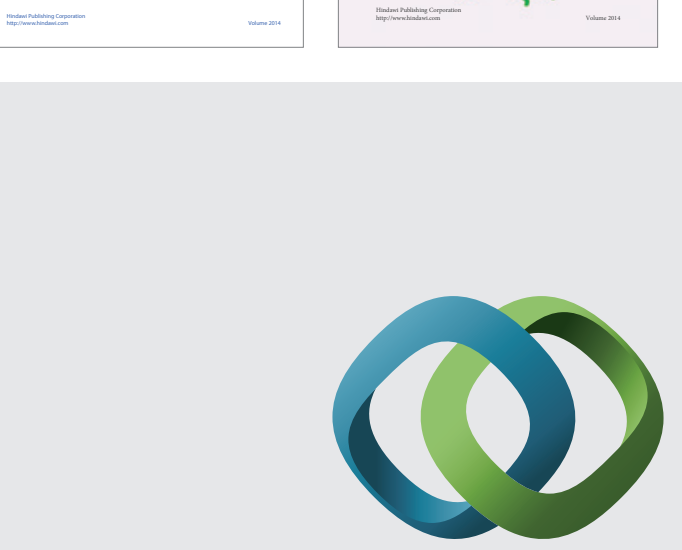

\section{Hindawi}

Submit your manuscripts at

http://www.hindawi.com
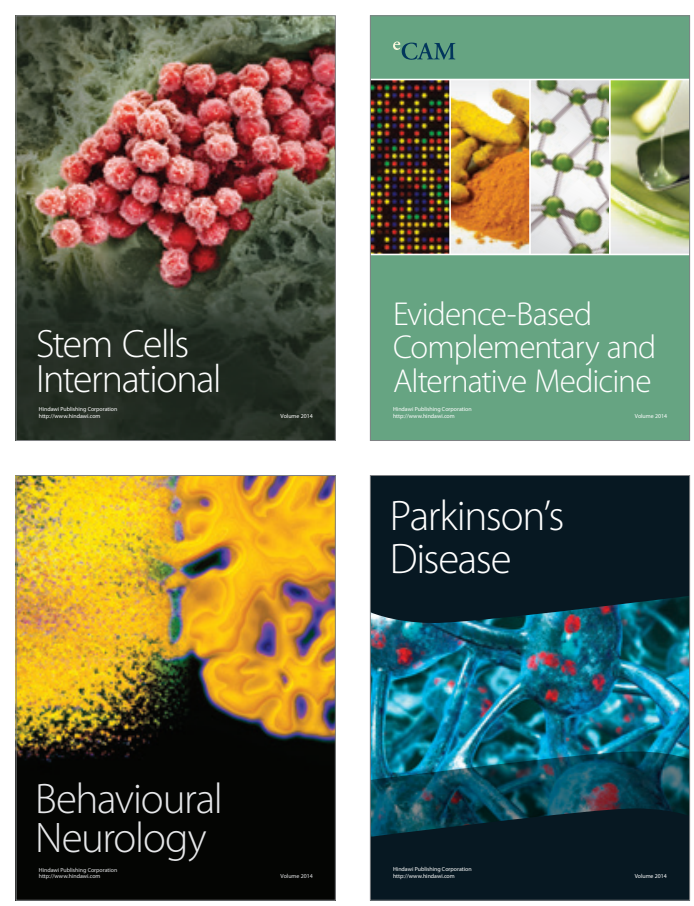

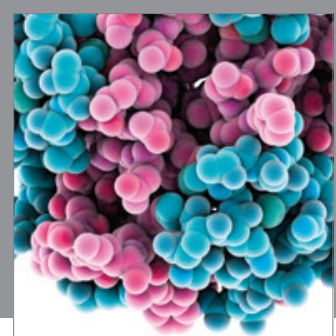

Journal of
Diabetes Research

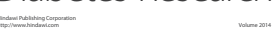

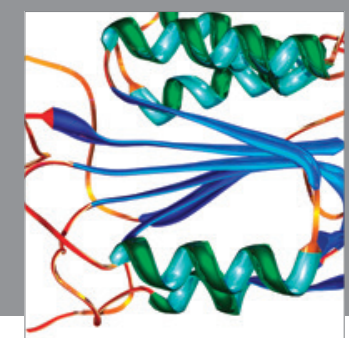

Disease Markers
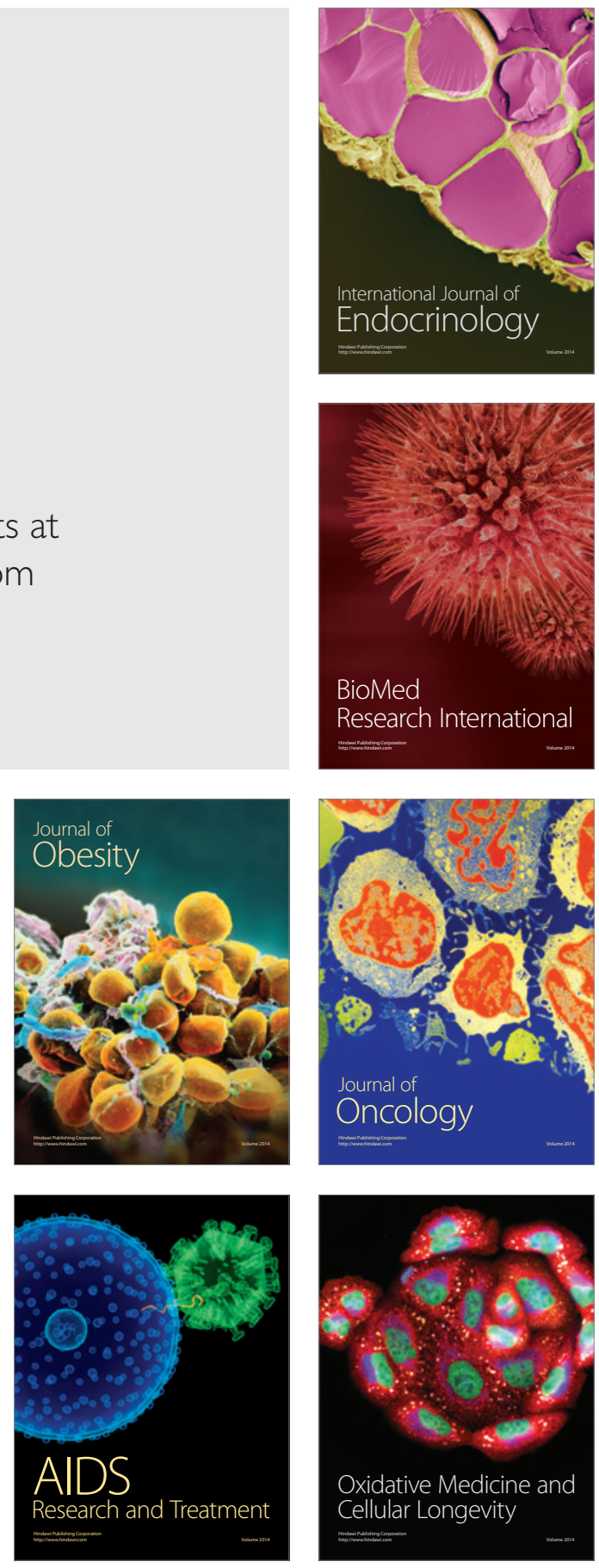